\title{
Systematic investigations of COVID-19 in 283 cancer patients
}

Jie Wang ${ }^{1 *}$, Qibin Song ${ }^{2 *}$, Yuan Chen ${ }^{3 *}$, Zhijie Wang ${ }^{1 *}$, Qian Chu ${ }^{3 *}$, Hongyun Gong ${ }^{2 *}$, Shangli $\mathrm{Cai}^{4 *}$, Xiaorong Dong ${ }^{5}$, Bin $\mathrm{Xu}^{2}$, Weidong $\mathrm{Hu}^{6}$, Qun Wang ${ }^{7}$, Linjun $\mathrm{Li}^{8}$, Jiyuan Yang $^{9}$, Zhibin $\mathrm{Xie}^{10}$, Zhiguo Luo ${ }^{11}$, Jing Liu ${ }^{12}$, Xiuli Luo ${ }^{13}$, Jie Ren ${ }^{14}$, Zhiguo Rao ${ }^{15}$, Xinhua $\mathrm{Xu}^{16}$, Dongfeng Pan ${ }^{17}$, Zuowei Hu${ }^{18}$, Gang Feng ${ }^{19}$, Chiding $\mathrm{Hu}^{20}$, Liqiong $\mathrm{Luo}^{21}$, Hongda $\mathrm{Lu}^{22}$, Ruizhi $\mathrm{Ran}^{23}$, Jun $\mathrm{Jin}^{24}$, Yanhua Xu ${ }^{25}$, Yong Yang ${ }^{26}$, Zhihong Zhang ${ }^{27}$, Li Kuang $^{28}$, Runkun Wang ${ }^{29}$, Youhong Dong ${ }^{30}$, Jianhai Sun ${ }^{31}$, Wenbing $\mathrm{Hu}^{32}$, Tienan $\mathrm{Yi}^{33}$, Hanlin $\mathrm{Wu}^{34}$, Mingyu Liu ${ }^{35}$, Jiachen $\mathrm{Xu}^{1}$, Jianchun Duan ${ }^{1}$, Zhengyi Zhao ${ }^{36}$, Guoqiang Wang ${ }^{4}, \mathrm{Yu} \mathrm{Xu}^{36}, \mathrm{Jie}^{37}$

\section{Affiliations:}

${ }^{1}$ State Key Laboratory of Molecular Oncology, Department of Medical Oncology, National Cancer Center/National Clinical Research Center for Cancer/Cancer Hospital, Chinese Academy of Medical Sciences \& Peking Union Medical College, Beijing 100021, China, ${ }^{2}$ Cancer Center, Renmin Hospital of Wuhan University, Wuhan, Hubei 430060, China, ${ }^{3}$ Department of Oncology, Tongji Hospital, Tongji Medical College, Huazhong University of Science and Technology, Wuhan, Hubei 430030, China, ${ }^{4}$ Burning Rock Biotech, Guangzhou 510300, China, ${ }^{5}$ Cancer Center, Union Hospital, Tongji Medical College, Huazhong University of Science and Technology, Wuhan, Hubei 430022, China, ${ }^{6}$ Department of thoracic Surgery, Zhongnan Hospital of Wuhan University, Wuhan, Hubei 430071, China, ${ }^{7}$ Department of Oncology, The Fifth Hospital of Wuhan, Wuhan, Hubei 430050, China, ${ }^{8}$ Department of Oncology, Hubei Provincial Hospital of Integrated Chinese and Western Medicine, Wuhan, Hubei 430071, China, ${ }^{9}$ Department of Oncology, First Affiliated Hospital of Yangtze University, Jingzhou, Hubei 434023, China, ${ }^{10}$ Department of Respiratory and Critical Care Medicine, Xiaogan Hospital Affiliated to Wuhan University of Science and Technology, Xiaogan, Hubei 432100, China, ${ }^{11}$ Department of Oncology, Taihe Hospital, Hubei University of Medicine, Shiyan, Hubei 442000, China, ${ }^{12}$ Department of Oncology, Huanggang Central Hospital, Huanggang, Hubei 438000, China, ${ }^{13}$ Department of Oncology, Hubei Provincial Hospital of TCM, Wuhan, Hubei 430000, China, ${ }^{14}$ Department of Medical Oncology, General Hospital of The Yangtze River Shipping, Wuhan, Hubei 430010, China, ${ }^{15}$ Department of Oncology, General Hospital of Central Theater Command, People's Liberation Army, Wuhan, Hubei 430070, China, ${ }^{16}$ Department of Oncology, Yichang Central People's Hospital, Yichang, Hubei 443003, China, ${ }^{17}$ Department of Oncology, Suizhou Hospital, HuBei University of Medicine, Suizhou, Hubei 441300, China, ${ }^{18}$ Department of Oncology, Wuhan No.1 Hospital, Wuhan, Hubei 430022, China, ${ }^{19}$ Department of Oncology, Wuhan Fourth Hospital (Puai Hospital), Tongji Medical College, Huazhong University of Science and Technology, Wuhan, Hubei 430000, China, ${ }^{20}$ Department of Oncology, Affiliated Hospital of Jianghan University, Wuhan, Hubei 430015, China, ${ }^{21}$ Department of Oncology, Tianyou Hospital Affiliated to Wuhan University of Science and Technology, Wuhan, Hubei 430064, China, ${ }^{22}$ Department of Oncology, The Central Hospital of Wuhan, Tongji Medical College, Huazhong University of Science and Technology, Wuhan, Hubei 430014, China, ${ }^{23}$ Department of Oncology, The Central Hospital of Enshi Tujia and Miao Autonomous Prefecture, Enshi, Hubei 445000, China, ${ }^{24}$ Department of Oncology, Ezhou Central Hospital, Ezhou, Hubei 436000, China, ${ }^{25}$ Department of Oncology, Jingzhou Central Hospital, Jingzhou, Hubei 434020, China, ${ }^{26}$ Department of oncology, The Second Hospital 
medRxiv preprint doi: https://doi.org/10.1101/2020.04.28.20083246; this version posted May 3, 2020. The copyright holder for this preprint (which was not certified by peer review) is the author/funder, who has granted medRxiv a license to display the preprint in perpetuity. It is made available under a CC-BY-NC-ND 4.0 International license .

47 of WISCO (Wuhan Iron and Steel Corporation), Wuhan, Hubei 430085, China, $48 \quad{ }^{27}$ Department of Oncology, Gong'an County People's Hospital, Jingzhou, Hubei 434300, 49 China, ${ }^{28}$ Department of Oncology, Affliated Dongfeng Hospital, Hubei University of 50 Medicine, Shiyan, Hubei 442008, China, ${ }^{29}$ Department of oncology, The first people's 51 hospital of Guangshui, Suizhou, Hubei 432700, China, ${ }^{30}$ Department of oncology, 52 Xiangyang No.1 People's Hospital, Hubei University of Medicine, Xiangyang, Hubei 53 441000, China, ${ }^{31}$ Department of Oncology, Hubei No.3 People's Hospital, Wuhan, Hubei 430033, China, ${ }^{32}$ Department of Oncology, Huangshi Central Hospital of EDong Healthcare, Huangshi, Hubei 435000, China, ${ }^{33}$ Department of Oncology, Xiangyang Central Hospital, Hubei Univeristy of Medicine, Xiangyang, Hubei 441021, China, ${ }^{34}$ Department of Oncology, The First People's Hospital of Jingmen, Jingmen, Hubei 448000, China, ${ }^{35}$ The No. 9 hospital of Wuhan, Wuhan, Hubei 430081, China, ${ }^{36}$ The Medical Department, 3D Medicines, Inc., Shanghai 201114, China, ${ }^{37}$ State Key Laboratory of Molecular Oncology, Department of Thoracic Surgery, National Cancer Center/National Clinical Research Center for Cancer/Cancer Hospital, Chinese Academy of Medical Sciences \& Peking Union Medical College, Beijing 100021, China

*Contributed equally.

\section{Correspondence to:}

Jie He, M.D., State Key Laboratory of Molecular Oncology, Department of Thoracic Surgery, National Cancer Center/ National Clinical Research Center for Cancer/Cancer Hospital, Chinese Academy of Medical Sciences \& Peking Union Medical College, Beijing, China, 17 Pan-jia-yuan South Lane, Chaoyang District, 100021, Beijing, China. hejie@cicams.ac.cn; Tel: 86-1087788207;

Jie Wang, M.D., Ph.D., State Key Laboratory of Molecular Oncology, Department of Medical Oncology, National Cancer Center/National Clinical Research Center for Cancer/Cancer Hospital, Chinese Academy of Medical Sciences \& Peking Union Medical College, Beijing, China, 17 Pan-jia-yuan South Lane, Chaoyang District, 100021, Beijing, China. zlhuxi@163.com; Tel: 86-13910704669. 
medRxiv preprint doi: https://doi.org/10.1101/2020.04.28.20083246; this version posted May 3, 2020. The copyright holder for this preprint (which was not certified by peer review) is the author/funder, who has granted medRxiv a license to display the preprint in perpetuity. It is made available under a CC-BY-NC-ND 4.0 International license .

\section{Abstracts}

Background: Cancer patients are considered to be highly susceptible to viral infections, however, the comprehensive features of COVID-19 in these patients remained largely unknown. The present study aimed to assess the clinical characteristics and outcomes of COVID-19 in a large cohort of cancer patients.

Design, Setting, and Participants: Data of consecutive cancer patients admitted to 33 designated hospitals for COVID-19 in Hubei province, China from December 17, 2019 to March 18, 2020 were retrospectively collected. The follow-up cutoff date was April 02, 2020. The clinical course and survival status of the cancer patients with COVID-19 were measured, and the potential risk factors of severe events and death were assessed through univariable and multivariable analyses.

Results: A total of 283 laboratory confirmed COVID-19 patients (50\% male; median age, 63.0 years [IQR, 55.0 to 70.0]) with more than 20 cancer types were included. The overall mortality rate was $18 \%(50 / 283)$, and the median hospitalization stay for the survivors was 26 days. Amongst all, 76 (27\%) were former cancer patients with curative resections for over five years without recurrence. The current cancer patients exhibited worse outcomes versus former cancer patients (overall survival, $\mathrm{HR}=2.45$, 95\% CI 1.10 to 5.44 , log-rank $p=0.02$; mortality rate, $21 \%$ vs $9 \%$ ). Of the 207 current cancer patients, 95 (46\%) have received recent anti-tumor treatment, and the highest mortality rate was observed in the patients receiving recent chemotherapy $(33 \%)$, followed by surgery $(26 \%)$, other antitumor treatments (19\%), and no anti-tumor treatment (15\%). In addition, a higher mortality rate was observed in patients with lymphohematopoietic malignancies (LHM) (53\%, 9/17), and all seven LHM patients with recent chemotherapy died. Multivariable analysis indicated that LHM ( $p=0.001)$ was one of the independent factors associating with critical illness or death.

Conclusions: This is the first systematic study comprehensively depicting COVID-19 in a large cancer cohort. Patients with tumors, especially LHM, may have poorer prognosis of COVID-19. Additional cares are warranted and non-emergency anti-tumor treatment should be cautiously used for these patients under the pandemic. 
medRxiv preprint doi: https://doi.org/10.1101/2020.04.28.20083246; this version posted May 3, 2020. The copyright holder for this preprint (which was not certified by peer review) is the author/funder, who has granted medRxiv a license to display the preprint in perpetuity.

It is made available under a CC-BY-NC-ND 4.0 International license .

Introduction

111 Since the publicly reported coronavirus disease 2019 (COVID-19) caused by severe acute

112 respiratory syndrome coronavirus-2 (SARS-CoV-2) infection in December, $2019^{1}$ and the

113 subsequent evidences of its human-to-human transmission property released in January

$1142020,^{2}$ there has been an extremely rapid spread of the novel coronavirus around the globe.

115 The World Health Organization (WHO) has declared a global health emergency on January

$11630,2020 .^{3}$ The first systematic description of the clinical characteristics of COVID-19 in

117 China was reported on February, 2020, showing a fatality rate of $1.4 \%$ among the 1,099

118 Chinese patients. ${ }^{4}$ Till April 02, 2020, the novel viral infection has caused 82,735 and

119855,446 cumulative cases in China and worldwide, with 3,327 and 43,955 reported death, 120 respectively. ${ }^{5}$

121 Cancer patients, as a special population who usually have a high demand for 122 intensive care and are frequently systematically immunosuppressed, are considered to be 123 more susceptible to the infection. ${ }^{6}$ Accordingly, a considerable amount of cancer patients 124 may have been subjected to COVID-19 during the pandemic, which has attracted 125 increasing attention from the clinicians. ${ }^{6-9}$ Recent studies with small cohorts ( $\mathrm{n}=12$ to 28$)$

126 of SARS-CoV-2 infected cancer patients have proposed the potentially higher 127 susceptibility and poorer prognosis of COVID-19 in cancer patients compared to the 128 overall population. ${ }^{6,8,10}$ However, the study population in these reports are too limited to 129 provide conclusive evidences, and the characteristics of COVID-19 in cancer patients 130 remained largely unknown. Herein, we carried out the present large retrospective study for 131 the comprehensive investigation of the clinical characteristics, prognosis, survival status, 132 and potential risk factors of severe events of COVID-19 in a large cohort of Chinese cancer 133 patients. 
medRxiv preprint doi: https://doi.org/10.1101/2020.04.28.20083246; this version posted May 3, 2020. The copyright holder for this preprint (which was not certified by peer review) is the author/funder, who has granted medRxiv a license to display the preprint in perpetuity.

It is made available under a CC-BY-NC-ND 4.0 International license .

\section{Methods}

\section{Study Population, Setting and Data Collection}

137 Consecutive cancer patients who were newly admitted to 33 designated hospitals for 138 COVID-19 in Hubei province, China between December 17, 2019 and March 18, 2020 139 were included. The follow-up cutoff date was April 02, 2020. The patients were admitted 140 to the hospitals for suspicious or confirmed SARS-CoV-2 infection irrespective of their on141 admission symptom levels, and all patients eventually got laboratory confirmed diagnosis

142 with COVID-19. The collection and tests of clinical specimens, diagnosis, treatment (anti143 tumor and anti-infections), examinations, and severity level assessment (asymptomatic, 144 mild, moderate, severe, and critical cases) of COVID-19 were performed following the 145 latest edition of Novel Coronavirus Pneumonia Diagnosis and Treatment Plan released by 146 the National Health Commission \& National Administration of Traditional Chinese 147 Medicine by assessment. Nasopharyngeal swabs were collected for pathogenic test using 148 RT-PCR assay to confirm the presence of 2019-nCoV nucleic acid.

149 Data of the demographic and clinicopathological characteristics, infection 150 symptoms, examination results (laboratory tests, chest CT scan, etc.), clinical treatments, 151 and survival outcomes were retrospectively collected from the electronic medical records 152 and further reviewed and confirmed by two independent physicians from each hospital. 153 The data were analyzed by two independent statisticians (GW and YuXu). All 154 inconsistencies were reviewed and confirmed by the Medical Review Board composed of 155 physicians from departments of oncology, thoracic surgery, and pulmonary and critical care 156 medicine. Patient identity protection was maintained throughout the study.

\section{Study Definitions}


medRxiv preprint doi: https://doi.org/10.1101/2020.04.28.20083246; this version posted May 3, 2020. The copyright holder for this preprint

158 Former cancer patients were defined as the patients who were diagnosed with malignancies

159 and have received curative surgical resections over five years without recurrence till the

160 hospital admission for COVID-19. Fever was defined as an axillary temperature of $37.5^{\circ} \mathrm{C}$

161 or higher. Acute respiratory distress syndrome (ARDS) was defined based on the interim

162 guidance for the management of critical COVID-19 by WHO. ${ }^{11}$ Recent anti-tumor

163 treatment were defined as the conventional anti-tumor treatment that were provided within

1643 months before the hospital admission for COVID-19. The types of conventional anti-

165 tumor treatment included: surgical resection, chemotherapy, radiotherapy, targeted therapy,

166 immunotherapy, and combinational therapy, etc. Critical cases were defined as patients

167 with ARDS and requiring mechanical ventilation or extracorporeal membrane oxygenation

168 (ECMO), shock, acute heart failure, acute myocardial infarction, or acute renal failure.

169 Hospitalization stay was defined as the date from hospital admission for COVID-19 till

170 discharge. Remission was defined as either the decrease of at least one-level on disease

171 severity, the change of nucleic acid test results from positive to negative, or the improved

172 absorption of inflammation upon pulmonary imaging. The overall survival (OS) was

173 defined as the time from the date of first clinical visit for suspicious infection of SARS-

174 CoV-2 until death due to any cause.

\section{Statistical Analysis}

176 The clinical pathological variables, symptoms, and chest CT scan results in the patients

177 were statistically described. Continuous variables were described by median (IQR) and

178 categorical variables were described by number (percentages). To assess the differences

179 between different subset of population, Mann-Whitney test was performed for continuous

180 variables and chi-square test was performed for categorical variables. For hospitalization

181 stay, Kaplan-Meier curves were plotted and compared by using a log-rank test with 
182 hazard's ratio determined by cox regression. Univariable and multivariable logistic

183 regression were used to test the associations between different variables and the critical

184 and death cases. For univariable analysis, baseline characteristics were tested with blood

185 biochemistry variables transformed into categorical variables with the cutoffs upon the

186 clinical relevance. Variables that achieved a significant level with $p<0.05$ and an odds

187 ratio $(\mathrm{OR})>3$ in the univariable analysis were selected for multivariable logistic regression

188 using stepwise forward conditional mode. When strong correlations were present among

189 the variables that met the above criteria, only the one with the highest odds ratio entered

190 the multivariable analysis. All reported $p$ values were two-tailed, and $p<0.05$ was

191 considered statistically significant. The analyses were performed with the use of R software

192 (version 3.5.0, R Foundation for Statistical Computing) and GraphPad Prism software

193 (version 5.0, GraphPad Software Inc.).

194 Results

\section{Clinical Characteristics}

196 A total of 283 cancer patients who were admitted to 33 designated hospitals with laboratory 197 confirmed diagnosis of COVID-19 were included in the study (Table 1). The median age 198 of the overall patients was 63.0 (IQR, 55.0-70.0) years, and 50\% were male patients. The 199 overall population harbored more than 20 types of tumor, including $51(18 \%)$ with lung 200 cancer, $38(13 \%)$ with breast cancer, and $34(12 \%)$ with colorectal cancer, etc. The most 201 common comorbidities were hypertension (33\%), diabetes (14\%), and cardiovascular 202 disease (11\%). At onset of illness, $6(2 \%), 97(34 \%), 108(38 \%)$, and $72(25 \%)$ of the 203 patients were asymptomatic, with mild, moderate, and severe symptoms, respectively. 204 Amongst all, 76 (27\%) were former cancer patients who have undergone primary resection 205 for over five years without relapse, 207 (73\%) were current cancer patients, including 101 
medRxiv preprint doi: https://doi.org/10.1101/2020.04.28.20083246; this version posted May 3, 2020. The copyright holder for this preprint (which was not certified by peer review) is the author/funder, who has granted medRxiv a license to display the preprint in perpetuity.

It is made available under a CC-BY-NC-ND 4.0 International license .

206 (49\%) with locally advanced or advanced diseases. Compared with the former cancer

207 patients, the current cancer patients were more likely to exhibit severe symptoms (29\% vs

$208 \quad 17 \%$ ) on admission.

The most common symptoms on admission were fever (73\%), cough (68\%), fatigue

210 (49\%), sputum (41\%), and dyspnea (40\%) (supplementary table S1). Baseline chest CT

211 scan presented ground glass opacity in 211 (75\%) patients, interstitial thickening in 112

$212(40 \%)$ patients, consolidation in $71(25 \%)$ patients, and reticular pattern in $60(21 \%)$

213 patients, which was similarly observed in the former and current cancer patients

214 (supplementary table S2).

215 Prognosis and outcomes

216 For treatment against COVID-19, antiviral, antibacterial, hormone, and immunoglobulin

217 therapies were provided for $262(93 \%), 233(82 \%), 113(40 \%)$, and $86(30 \%)$ patients,

218 respectively. The clinical courses of the patients throughout hospitalization were provided

219 for the overall population (figure 1), the former cancer patients (supplementary figure S1),

220 and the current cancer patients (supplementary figure S2). The overall mortality rate was

221 18\% (50/283), including 17\% (47/283) deaths due to COVID-19. During hospitalization,

22219 mild cases, 34 moderate cases, and 72 severe cases eventually developed severe (62

$223[22 \%])$ and critical (63 [22\%]) cases. Of the critical cases, $45(71 \%)$ died by the last visit,

224 accounting for $90 \%$ of the overall death cases (figure 1). The most common complications

225 were ARDS (85, 30\%), stroke (42, 15\%), and acute heart failure (17, 6\%). Non-invasive

226 and invasive mechanical ventilations were provided for $51(18 \%)$ and $18(6 \%)$ patients,

227 respectively. At the last follow up, there were $178(63 \%)$ asymptomatic cases and $2(1 \%)$

228 severe cases (figure 1). 
medRxiv preprint doi: https://doi.org/10.1101/2020.04.28.20083246; this version posted May 3, 2020. The copyright holder for this preprint (which was not certified by peer review) is the author/funder, who has granted medRxiv a license to display the preprint in perpetuity. It is made available under a CC-BY-NC-ND 4.0 International license . patients, 91\% (69/76) in the former cancer patients, and 78\% $(161 / 207)$ in the current

232 cancer patients, respectively. The recovery degree as represented by the ratio of 233 asymptomatic patients by the last follow-up visit was $63 \%(178 / 283)$ in the overall 234 population, $68 \%(52 / 76)$ in the former cancer patients, and $61 \%(126 / 207)$ in the current 235 cancer patients, respectively. As shown, the worst prognosis was observed in the patients 236 with current lymphohematopoietic malignancies (LHM) including lymphoma $(\mathrm{n}=8)$ and 237 leukemia $(n=9)$, followed by esophageal cancer $(n=9)$ and lung cancer $(n=51)$, with 238 a remission rate of $38 \%, 44 \%, 67 \%$, and $70 \%$, and a degree of recovery of $38 \%, 22 \%, 44 \%$, 239 and 54\%, respectively (figure 2, supplementary table S3). In addition, the LHM patients 240 were more likely to develop severe or critical cases $(59 \%, 10 / 17$ vs $22 \%, 41 / 190)$ and 241 deaths $(53 \%, 9 / 17$ vs 18\%, 34/190) compared to patients with solid tumors (supplementary 242 Table S4), and all the seven LHM patients with recent chemotherapy died. 246 stay (26 days vs 25 days, figure 3C) and significantly higher risk of death compared to the

247 former cancer patients (OS, HR 2.45, 95\%CI 1.10-5.44, $\log$-rank $p=.023)$, with a mortality 248 rate of $21 \%(43 / 207)$ and $9 \%(7 / 76)$, respectively (figure 3D). Of the 207 current cancer 249 patients, $95(46 \%)$ have received recent anti-tumor treatments, including $46(22 \%)$ with 250 chemotherapy, $23(11 \%)$ with surgical resection, and $26(13 \%)$ with other anti-tumor 251 treatments. Among them, the highest mortality rate was observed in the patients treated 252 with recent chemotherapy (33\%), followed by surgery $(26 \%)$, other treatments (19\%), and 
medRxiv preprint doi: https://doi.org/10.1101/2020.04.28.20083246; this version posted May 3, 2020. The copyright holder for this preprint (which was not certified by peer review) is the author/funder, who has granted medRxiv a license to display the preprint in perpetuity.

It is made available under a CC-BY-NC-ND 4.0 International license .

253 no treatment (15\%) (supplementary figure S3). Two patients have received recent

254 immunotherapy as monotherapy, including one stage IV lung cancer patient with mild

255 symptoms at diagnosis, experienced severe illness during hospitalization, got recovered

256 after treatment and discharged with 31-day hospitalization stay, and another patient with

257 stage IV urothelial cancer who had moderate symptoms as the worst status and got

258 discharged after recovery with 26 days of hospitalization stay.

\section{Risk factors}

260 Logistic regression analyses were conducted to investigate the potential risk factors 261 associated with disease severity in COVID-19 cancer patients. Demographic and clinical 262 characteristics, symptoms, CT findings and laboratory findings were included for analysis.

263 Multivariable analysis indicated that lymphohematopoietic malignancies $(p=0.001)$,

264 severe symptoms at first clinical visit $(p=0.012)$, and elevated levels of neutrophil $(>$

$\left.2656.3 \times 10^{9} / \mathrm{mL}, p=3.00 \times 10^{-6}\right)$, direct bilirubin $(\mathrm{DBIL})(>7 \mu \mathrm{mol} / \mathrm{L}, p=0.001)$, creatinine

$266(>115 \mu \mathrm{M}, p=0.007)$, and troponin $(>5 \mathrm{ng} / \mathrm{ml}, p=0.033)$ at baseline were independent

267 risk factors associated with the development of critical illness or deaths (table 2). No

268 significant association was observed between the cancer status (current vs former) with 269 critical or death cases.

\section{Discussion}

272 The rapid spreading of COVID-19 has swept the globe, leading to a worldwide pandemic.

273 The present study has provided the first comprehensive depiction of the clinicopathological

274 characteristics, clinical outcomes, and risk factors for death of COVID-19 in patients with

275 tumors. Our study highlighted the poorer prognosis of COVID-19 in cancer patients, which

276 may provide valuable clues for the patient management under the current coronavirus 
medRxiv preprint doi: https://doi.org/10.1101/2020.04.28.20083246; this version posted May 3, 2020. The copyright holder for this preprint (which was not certified by peer review) is the author/funder, who has granted medRxiv a license to display the preprint in perpetuity.

It is made available under a CC-BY-NC-ND 4.0 International license .

277

278

279

280

281

282

283

284

285

286

287

288

289

290

291

292

293

294

295

296

297

298

299

300

disease pandemic.

In our cohort of 283 cancer patients with COVID-19 infection, the median hospitalization stay was 26 days, which is longer than the previously reported 12 days $^{4}$ in the unselected COVID-19 cases and 16 days in the severe cases. ${ }^{12}$ Recent study reported that the mortality rate was $28.6 \%$ in $28 \mathrm{SARS}-\mathrm{CoV}-2$ infected cancer patients, ${ }^{8}$ our analysis further provided a mortality rate of $18 \%$, with $9 \%$ in former cancer patients and $21 \%$ in current cancer patients, both higher than that of the overall cumulative mortality rate of COVID-19 cases as reported in Hubei province (4.7\%) over the same period (as of April $02,2020),{ }^{5}$ indicating the worse outcomes in the patients with a history of cancer when infected by the novel coronavirus.

A statistically significantly shorter overall survival was observed in the current cancer patients compared to the former cancer patients, and the difference was larger when the patients received recent anti-tumor treatment, especially chemotherapy, which is most likely to weaken the immune system among different treatments. For patients with LHM, who often have a severely defective immune system upon the largely replacement of normal functional immune cells by malignant cells, a higher prevalence was observed in the studied cohort $(6.0 \%, 3.2 \%$ for leukemia and $3.5 \%$ for lymphoma), which almost doubles that of the prevalence of LHM in the overall cancer population in China $(3.8 \%$, $1.8 \%$ for leukemia and $2.1 \%$ for lymphoma), ${ }^{13}$ indicating that these patients may be more susceptible to SARS-CoV-2 infection. In addition, an even higher rate of death cases was observed in patients with LHM (53\%) compared with the patients with solid tumors (18\%), and all of the LHM patients who were treated with recent chemotherapy died. Collectively, our results further suggested that the worse outcomes in SARS-CoV-2 infected cancer patients may be attributed to both the intrinsic immunocompromised status from the 
medRxiv preprint doi: https://doi.org/10.1101/2020.04.28.20083246; this version posted May 3, 2020. The copyright holder for this preprint (which was not certified by peer review) is the author/funder, who has granted medRxiv a license to display the preprint in perpetuity. It is made available under a CC-BY-NC-ND 4.0 International license .

301

malignancies and the immunosuppression caused by active anti-tumor treatments. Accordingly, anti-tumor treatment, especially chemotherapy, should be used with great caution to reduce the potential negative effects on the patients.

Previous reports suggested that age and coexisting conditions were potential risk factors associated with disease severity. ${ }^{14-16}$ Given the higher median age in our cancer cohort (63 years) than the reported median age of 47-year-old in the general COVID-19 patients, the effect of age on the disease severity was weakened, providing a relatively lower level of significance (OR, 1.94, 95\%CI 1.12-3.37) in the univariable analysis compared to the other variables (table 2). Our study further showed that LHM, an elevated baseline neutrophil, DBIL, creatinine, troponin, and the severe symptoms at onset illness were independently associated with the development of critical or death cases in cancer patients with COVID-19, which may provide important implications for the patient cares. There are several limitations in this study. Firstly, this study was conducted in a retrospective setting. Nevertheless, the patient population in this study was relatively large, and the patients were consecutively included irrespective of their baseline characteristics including the clinical symptoms, which will reduce the potential bias of the study population. Secondly, this study focused on the investigation of patients with cancer infected with SARS-CoV-2, and no direct comparison was conducted between the infected cancer patients and the non-cancer patients. Despite that, comparisons have been made between the current and the former cancer patients, who were considered to exhibit relatively more likely to cancer-free patients as a reference. Besides, the studied population came from as many as 33 designated hospitals in Hubei province, China, which is considered to be fairly representative for the overall condition of COVID-19 cancer patients in Hubei province, and thus was compared with the data of general COVID-19 
medRxiv preprint doi: https://doi.org/10.1101/2020.04.28.20083246; this version posted May 3, 2020. The copyright holder for this preprint (which was not certified by peer review) is the author/funder, who has granted medRxiv a license to display the preprint in perpetuity.

It is made available under a CC-BY-NC-ND 4.0 International license .

325 patients in Hubei province over the same period.

\section{Conclusion}

328 Our study provided the first systematic investigations of the clinical characterization, 329 outcomes, and risk factors for disease severity of COVID-19 patients with malignancies.

330 The results indicated a potentially higher susceptibility and poorer prognosis of patients 331 with a history of cancer when infected with SARS-CoV-2. Given that there are no 332 confirmed effective drugs for the prevention or treatment of COVID-19 to date, strict preventions and special cares are warranted for patients with malignancies to minimize the

334 potential risks and impacts from infections under the pandemic.

Contributors: JW and JH contributed equally to this paper and are joint corresponding authors. JW, QS, YC, ZW, QC, HG, and SC are joint first authors. All corresponding and first authors contributed to study concept and design. JW, ZW, SC, QS, QC, GW, YuXu, and ZZhao contributed to the acquisition, analysis, and interpretation of data. JW, ZW, SC,

$340 \mathrm{GW}, \mathrm{YuXu}$, and ZZhao wrote the first draft of the report. All authors approved the final

341 version of the report. JH and JW were responsible for the integrity and accuracy of the data

342 and is the guarantor. The corresponding authors attest that all listed authors meet authorship 343 criteria and that no others meeting the criteria have been omitted.

344 Funding: This work was supported by the CAMS Initiative for Innovative Medicine 345 (CAMS 2020-I2M-CoV19-004). The funding sources had no role in the design and conduct 346 of the study; collection, management, analysis, and interpretation of the data; preparation, 347 review, or approval of the manuscript; and decision to submit the manuscript for 348 publication. 
medRxiv preprint doi: https://doi.org/10.1101/2020.04.28.20083246; this version posted May 3, 2020. The copyright holder for this preprint (which was not certified by peer review) is the author/funder, who has granted medRxiv a license to display the preprint in perpetuity.

It is made available under a CC-BY-NC-ND 4.0 International license .

349 Competing interests: All authors declare no competing interests.

350 Ethical approval: This study was approved by the Ethics Committee of the National 351 Cancer Center (No. 20/061-2257, Beijing, China). The requirement for informed patient 352 consent was waived by the ethics committee due to the urgent of data collection.

353 Data sharing: The data that support the findings of this study are available from the 354 corresponding author on reasonable request.

355 The manuscript's guarantor affirms that the manuscript is an honest, accurate, and 356 transparent account of the study being reported; that no important aspects of the study have 357 been omitted; and that any discrepancies from the study as planned and registered have 358 been explained.

359 References

360 1. Huang C, Wang Y, Li X, et al. Clinical features of patients infected with 2019 novel 361 coronavirus in Wuhan, China. Lancet. Feb 15 2020;395(10223):497-506.

362 2. Li Q, Guan X, Wu P, et al. Early Transmission Dynamics in Wuhan, China, of Novel 363 Coronavirus-Infected Pneumonia. The New England journal of medicine. Mar 26 $364 \quad 2020 ; 382(13): 1199-1207$.

365 3. World Health Organization. Coronavirus diease (COVID-19) pandemic. . 2020, 3662020.

367 4. Guan WJ, Ni ZY, Hu Y, et al. Clinical Characteristics of Coronavirus Disease 2019 368 in China. The New England journal of medicine. Feb 282020.

369 5. Tencent Epidemic Situation Tracker. 2020, 2020.

370 6. Liang W, Guan W, Chen R, et al. Cancer patients in SARS-CoV-2 infection: a 371 nationwide analysis in China. The Lancet. Oncology. Mar 2020;21(3):335-337.

372 7. Wang Z, Wang J, He J. Active and Effective Measures for the Care of Patients with 
medRxiv preprint doi: https://doi.org/10.1101/2020.04.28.20083246; this version posted May 3, 2020. The copyright holder for this preprint (which was not certified by peer review) is the author/funder, who has granted medRxiv a license to display the preprint in perpetuity. It is made available under a CC-BY-NC-ND 4.0 International license.

373 Cancer During the COVID-19 Spread in China. JAMA oncology. 2020; In press.

374 8. Zhang L, Zhu F, Xie L, et al. Clinical characteristics of COVID-19-infected cancer

375 patients: A retrospective case study in three hospitals within Wuhan, China. Annals

376 of oncology : official journal of the European Society for Medical Oncology. Mar

$377 \quad 262020$.

378 9. Yu J, Ouyang W, Chua MLK, Xie C. SARS-CoV-2 Transmission in Patients With

379 Cancer at a Tertiary Care Hospital in Wuhan, China. JAMA oncology. 2020.

380 10. Yu J, Ouyang W, Chua MLK, Xie C. SARS-CoV-2 Transmission in Patients With

Cancer at a Tertiary Care Hospital in Wuhan, China. JAMA oncology. Mar 252020.

382 11. World Health Organization. Clinical management of severe acute respiratory infection when novel coronavirus ( $\mathrm{nCoV}$ ) infection is suspected. Interim guidance.

385 12. Cao B, Wang Y, Wen D, et al. A Trial of Lopinavir-Ritonavir in Adults Hospitalized

13. Chen W, Zheng R, Baade PD, et al. Cancer statistics in China, 2015. CA: a cancer with Severe Covid-19. The New England journal of medicine. Mar 182020. journal for clinicians. Mar-Apr 2016;66(2):115-132.

14. Chen N, Zhou M, Dong X, et al. Epidemiological and clinical characteristics of 99 cases of 2019 novel coronavirus pneumonia in Wuhan, China: a descriptive study.

392 15. Bhatraju PK, Ghassemieh BJ, Nichols M, et al. Covid-19 in Critically Ill Patients 393 394 in the Seattle Region - Case Series. The New England journal of medicine. Mar 30 2020.

395 16. Wu C, Chen X, Cai Y, et al. Risk Factors Associated With Acute Respiratory 396 Distress Syndrome and Death in Patients With Coronavirus Disease 2019 
medRxiv preprint doi: https://doi.org/10.1101/2020.04.28.20083246; this version posted May 3,2020. The copyright holder for this preprint (which was not certified by peer review) is the author/funder, who has granted medRxiv a license to display the preprint in perpetuity. It is made available under a CC-BY-NC-ND 4.0 International license . 
medRxiv preprint doi: https://doi.org/10.1101/2020.04.28.20083246; this version posted May 3, 2020. The copyright holder for this preprint (which was not certified by peer review) is the author/funder, who has granted medRxiv a license to display the preprint in perpetuity.

It is made available under a CC-BY-NC-ND 4.0 International license .

400 Table 1. Demographic, clinical, laboratory findings of cancer patients at the first clinical visit.

\begin{tabular}{|c|c|c|c|c|}
\hline & & $\begin{array}{c}\text { Total } \\
(\mathbf{n}=\mathbf{2 8 3})\end{array}$ & $\begin{array}{c}\text { Former cancer } \\
\text { patients } \\
(\mathbf{n}=76)\end{array}$ & $\begin{array}{c}\text { Current cancer } \\
\text { patients } \\
(\mathbf{n}=\mathbf{2 0 7})\end{array}$ \\
\hline \multicolumn{5}{|c|}{ Demographic and clinical characteristics } \\
\hline Age & & $63.0(55.0-70.0)$ & $65.0(60.0-73.0)$ & $62.0(53.0-69.0)$ \\
\hline \multicolumn{5}{|l|}{ Sex } \\
\hline & Female & $142(50)$ & $45(59)$ & $97(47)$ \\
\hline & Male & $141(50)$ & $31(41)$ & $110(53)$ \\
\hline \multicolumn{5}{|c|}{ Smoking history } \\
\hline & Current & $11(4)$ & $1(1)$ & $10(5)$ \\
\hline & Former & $54(19)$ & $10(13)$ & $44(21)$ \\
\hline & Never & $216(76)$ & $65(86)$ & $151(73)$ \\
\hline & NA & $2(1)$ & $0(0)$ & $2(1)$ \\
\hline \multicolumn{5}{|c|}{ Drinking history } \\
\hline & Current & $11(4)$ & $1(1)$ & $10(5)$ \\
\hline & Former & $41(14)$ & $5(7)$ & $36(17)$ \\
\hline & Never & $210(74)$ & $69(91)$ & $141(68)$ \\
\hline & NA & $21(7)$ & $1(1)$ & $20(10)$ \\
\hline \multicolumn{5}{|c|}{ Huanan market exposure } \\
\hline & No & $254(90)$ & $67(88)$ & $187(90)$ \\
\hline & Yes & $10(4)$ & $4(5)$ & $6(3)$ \\
\hline & NA & $19(7)$ & $5(7)$ & $14(7)$ \\
\hline \multicolumn{5}{|c|}{ Symptoms at the first visit } \\
\hline & Asymptomatic & $6(2)$ & $1(1)$ & $5(2)$ \\
\hline & Mild & $97(34)$ & $26(34)$ & $71(34)$ \\
\hline & Moderate & $108(38)$ & $36(47)$ & $72(35)$ \\
\hline & Severe & $72(25)$ & $13(17)$ & $59(29)$ \\
\hline \multicolumn{5}{|c|}{ Pathology } \\
\hline & Lung cancer & $51(18)$ & $5(7)$ & $46(22)$ \\
\hline & Breast cancer & $38(13)$ & $17(22)$ & $21(10)$ \\
\hline & Colorectal cancer & $34(12)$ & $14(18)$ & $20(10)$ \\
\hline & Thyroid carcinoma & $23(8)$ & $7(9)$ & $16(8)$ \\
\hline & Gastric cancer & $18(6)$ & $5(7)$ & $13(6)$ \\
\hline & Cervical cancer & $11(4)$ & $5(7)$ & $6(3)$ \\
\hline & Leukemia & $11(4)$ & $2(3)$ & $9(4)$ \\
\hline & Urothelial cancer & $11(4)$ & $4(5)$ & $7(3)$ \\
\hline & Lymphoma & $10(4)$ & $2(3)$ & $8(4)$ \\
\hline & Esophageal cancer & $9(3)$ & $0(0)$ & $9(4)$ \\
\hline & Hepatocellular carcinoma & $9(3)$ & $1(1)$ & $8(4)$ \\
\hline & Head and neck cancer & $7(2)$ & $4(5)$ & $3(1)$ \\
\hline & Ovarian cancer & $5(2)$ & $1(1)$ & $4(2)$ \\
\hline & Prostate cancer & $5(2)$ & $1(1)$ & $4(2)$ \\
\hline & Sarcoma & $5(2)$ & $1(1)$ & $4(2)$ \\
\hline & Pancreatic cancer & $4(1)$ & $0(0)$ & $4(2)$ \\
\hline & Renal cell carcinoma & $4(1)$ & $0(0)$ & $4(2)$ \\
\hline & Others & $28(10)$ & $7(9)$ & $21(10)$ \\
\hline \multicolumn{5}{|c|}{ Recent anti-cancer treatment } \\
\hline & No & $188(66)$ & $76(100)$ & $112(54)$ \\
\hline & Surgery & $23(8)$ & $0(0)$ & $23(11)$ \\
\hline
\end{tabular}


medRxiv preprint doi: https://doi.org/10.1101/2020.04.28.20083246; this version posted May 3, 2020. The copyright holder for this preprint (which was not certified by peer review) is the author/funder, who has granted medRxiv a license to display the preprint in perpetuity.

It is made available under a CC-BY-NC-ND 4.0 International license .

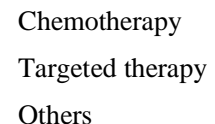

Diabetes

No

Hypertension

$$
\text { Yes }
$$$$
\text { No }
$$$$
\text { Yes }
$$

Cardiovascular comorbidity

$$
\text { No }
$$$$
\text { Yes }
$$

Cerebrovascular comorbidity

No
Yes

COPD

$$
\begin{aligned}
& \text { No } \\
& \text { Yes }
\end{aligned}
$$

Chronic liver disease

No
Yes

Chronic renal disease

$$
\begin{aligned}
& \text { No } \\
& \text { Yes }
\end{aligned}
$$

Laboratory findings

$\begin{array}{ll}\text { Leukocyte } & \times 10^{9} / \mathrm{mL} \\ \text { Neutrophil } & \times 10^{9} / \mathrm{mL} \\ \text { Lymphocyte } & \times 10^{9} / \mathrm{mL} \\ \text { Monocyte } & \times 10^{9} / \mathrm{mL} \\ \text { Eosinophil } & \times 10^{9} / \mathrm{mL} \\ \text { Basophil } & \times 10^{9} / \mathrm{mL} \\ \text { Platelet } & \times 10^{9} / \mathrm{mL} \\ \text { ALT } & \mathrm{U} / \mathrm{L} \\ \text { AST } & \mathrm{U} / \mathrm{L} \\ \text { TBIL } & \mu \mathrm{mol} / \mathrm{L} \\ \text { DBIL } & \mu \mathrm{mol} / \mathrm{L} \\ \text { Urea } & \mathrm{mM} \\ \text { Creatinine } & \mu \mathrm{M} \\ \text { Prothrombin time } & \mathrm{s} \\ \text { APTT } & \mathrm{s} \\ \text { D-dimer } & \mu \mathrm{g} / \mathrm{mL} \\ \text { CK-MB } & \mathrm{U} / \mathrm{L} \\ \text { Troponin } & \mathrm{ng} / \mathrm{ml} \\ \text { CRP } & \mathrm{mg} / \mathrm{L} \\ \text { hsCRP } & \mathrm{mg} / \mathrm{L} \\ \text { Procalcitonin } & \mathrm{ng} / \mathrm{mL}\end{array}$

$$
\begin{gathered}
46(16) \\
12(4)
\end{gathered}
$$$$
14(5)
$$

244 (86)

39 (14)

189 (67)

94 (33)

251 (89)

32 (11)

264 (93)

19 (7)

263 (93)

20 (7)

269 (95)

14 (5)

273 (96)

$10(4)$

$5.46(4.16-7.23)$

$3.86(2.59-5.47)$

$0.86(0.57-1.34)$

$0.42(0.30-0.60)$

$0.03(0.00-0.08)$

$0.01(0.01-0.02)$

188 (121-247)

$22.0(13.0-36.8)$

$28.0(19.0-39.0)$

$10.8(7.88-14.8)$

$3.70(2.50-5.43)$

$4.88(3.62-6.90)$

$64.1(53.0-84.0)$

$12.8(11.8-13.8)$

$33.3(28.7-38.4)$

$0.83(0.36-2.00)$

$1.31(0.60-6.20)$

$0.08(0.01-3.20)$

$26.5(5.82-70.2)$

$27.1(5.00-64.3)$

$0.11(0.05-0.26)$

$\begin{array}{lc}0(0) & 46(22) \\ 0(0) & 12(6) \\ 0(0) & 14(7)\end{array}$

60 (79)

184 (89)

$23(11)$

144 (70)

63 (30)

187 (90)

20 (10)

198 (96)

9 (4)

188 (91)

19 (9)

195 (94)

12 (6)

201 (97)

6 (3)

$\begin{array}{cc}5.61(4.53-6.84) & 5.37(3.90-7.26) \\ 3.81(2.77-4.84) & 3.86(2.54-5.76) \\ 0.98(0.72-1.54) & 0.80(0.52-1.28) \\ 0.44(0.37-0.61) & 0.39(0.26-0.59) \\ 0.05(0.01-0.09) & 0.02(0.00-0.08) \\ 0.01(0.01-0.02) & 0.01(0.00-0.02) \\ 222(169-272) & 179(104-227) \\ 22.3(15.8-33.3) & 21.5(12.0-38.4) \\ 25.0(19.0-39.0) & 28.5(19.0-39.0) \\ 11.1(9.35-14.5) & 10.5(7.40-15.0) \\ 3.40(2.50-4.30) & 4.00(2.60-6.20) \\ 5.00(4.00-6.23) & 4.80(3.40-7.47) \\ 64.5(55.0-83.8) & 64.1(52.0-84.0) \\ 12.7(11.6-13.4) & 12.8(11.9-14.0) \\ 32.9(28.4-37.7) & 33.5(28.8-38.6) \\ 0.57(0.24-1.54) & 0.93(0.47-2.49) \\ 1.41(0.90-4.46) & 1.12(0.50-8.00) \\ 0.02(0.01-2.20) & 1.69(0.01-3.60) \\ 15.8(5.00-56.0) & 29.3(6.20-72.4) \\ 22.2(5.00-56.6) & 28.0(5.00-68.0) \\ 0.08(0.03-0.13) & 0.12(0.05-0.34)\end{array}$

$5.61(4.53-6.84)$

5.37 (3.90-7.26)

3.86 (2.54-5.76)

$0.80(0.52-1.28)$

$0.02(0.00-0.08)$

(0.00-0.02)

$21.5(12.0-38.4)$

28.5 (19.0-39.0)

$10.5(7.40-15.0)$

4.80 (3.40-7.47)

$64.1(52.0-84.0)$

12.8 (11.9-14.0)

33.5 (28.8-38.6)

(0.93

$1.12(0.50-8.00)$

1.69 (0.01-3.60)

0.12 (0.05-0.34)

401 Data are median (IQR), or $\mathrm{n}(\%)$. Abbreviations: NA=not applicable; COPD=chronic obstructive pulmonary disease;

402 ALT=alanine aminotransferase; AST=aspartate aminotransferase; TBIL=total bilirubin. DBIL=direct bilirubin; 403 APTT=activated partial thromboplastin time; $\mathrm{CK}-\mathrm{MB}=$ creatine kinase-MB; $\mathrm{CRP}=\mathrm{C}$-reactive protein; hsCRP=high 404 sensitivity C-reactive protein. 
medRxiv preprint doi: https://doi.org/10.1101/2020.04.28.20083246; this version posted May 3, 2020. The copyright holder for this preprint (which was not certified by peer review) is the author/funder, who has granted medRxiv a license to display the preprint in perpetuity.

It is made available under a CC-BY-NC-ND 4.0 International license .

Table 2. Risk factors at the first clinical visit associated with critical ill or death.

\begin{tabular}{|c|c|c|c|c|c|}
\hline & Comparison & $\begin{array}{l}\text { Univariable } \\
\text { OR }(95 \% \mathrm{CI})\end{array}$ & $p$ value & $\begin{array}{l}\text { Multivariable } \\
\text { OR (95\% CI) }\end{array}$ & $p$ value \\
\hline \multicolumn{6}{|c|}{ Demographic and clinical characteristics } \\
\hline year & $>65$ vs. $\leq 65$ & $1.94(1.12-3.37)$ & 0.02 & & \\
\hline Sex & Female vs. male & $0.67(0.39-1.16)$ & 0.16 & & \\
\hline \multirow[t]{3}{*}{ Smoking history } & No (ref.) & & & & \\
\hline & Current vs. ref. & $0.78(0.16-3.72)$ & 0.75 & & \\
\hline & Former vs. ref. & $1.61(0.83-3.10)$ & 0.16 & & \\
\hline \multirow[t]{3}{*}{ Drinking history } & No (ref.) & & & & \\
\hline & Current vs. ref. & $0.75(0.16-3.59)$ & 0.72 & & \\
\hline & Former vs. ref. & $1.40(0.66-2.94)$ & 0.38 & & \\
\hline Huanan market exposure & Yes vs. no & $0.77(0.16-3.74)$ & 0.75 & & \\
\hline \multirow[t]{5}{*}{ Cancer history } & Former (ref.) & & & & \\
\hline & Current vs. ref. & $1.98(0.99-3.94)$ & 0.052 & & \\
\hline & LHM vs. ref. & $9.78(3.03-31.51)$ & $1.34 * 10^{-4}$ & $40.02(4.35-368.69)$ & 0.001 \\
\hline & Lung cancer vs. ref. & $3.13(1.32-7.38)$ & 0.009 & $1.69(0.32-8.95)$ & 0.54 \\
\hline & Other cancers vs. ref. & $1.29(0.61-2.70)$ & 0.51 & $1.00(0.22-4.52)$ & 1.00 \\
\hline \multirow[t]{5}{*}{ Recent anti-cancer treatment } & No treatment (ref.) & & & & \\
\hline & Any treatment vs. ref. & $1.93(1.11-3.38)$ & 0.021 & & \\
\hline & Surgery vs. ref. & $1.43(0.53-3.88)$ & 0.48 & & \\
\hline & Chemotherapy vs. ref. & $2.38(1.18-4.78)$ & 0.015 & & \\
\hline & Others vs. ref. & $1.71(0.69-4.20)$ & 0.24 & & \\
\hline Diabetes & Yes vs. no & $0.42(0.16-1.13)$ & 0.085 & & \\
\hline Hypertension & Yes vs. no & $1.58(0.90-2.78)$ & 0.11 & & \\
\hline Cardiovascular comorbidity & Yes vs. no & $2.84(1.33-6.07)$ & 0.007 & & \\
\hline Cerebrovascular comorbidity & Yes vs. no & $0.83(0.27-2.60)$ & 0.75 & & \\
\hline COPD & Yes vs. no & $2.26(0.88-5.77)$ & 0.090 & & \\
\hline Chronic liver disease & Yes vs. no & $0.86(0.23-3.16)$ & 0.82 & & \\
\hline Chronic renal disease & Yes vs. no & $0.78(0.16-3.78)$ & 0.76 & & \\
\hline \multicolumn{6}{|l|}{ Symptoms } \\
\hline Symptoms at the first visit & Severe vs. non-severe & $5.10(2.82-9.23)$ & $7.16^{*} 10^{-8}$ & $5.43(1.46-20.24)$ & 0.012 \\
\hline Fever & Yes vs. no & $0.77(0.42-1.42)$ & 0.40 & & \\
\hline Cough & Yes vs. no & $1.51(0.82-2.81)$ & 0.19 & & \\
\hline Sputum & Yes vs. no & $2.12(1.22-3.70)$ & 0.008 & & \\
\hline Dyspnea & Yes vs. no & $4.14(2.31-7.39)$ & $2.00 * 10^{-6}$ & & \\
\hline Fatigue & Yes vs. no & $1.74(1.00-3.03)$ & 0.052 & & \\
\hline Headache & Yes vs. no & $1.53(0.56-4.19)$ & 0.41 & & \\
\hline Muscle ache & Yes vs. no & $0.54(0.20-1.46)$ & 0.22 & & \\
\hline Sore throat & Yes vs. no & $1.18(0.36-3.83)$ & 0.79 & & \\
\hline Diarrhea & Yes vs. no & $0.63(0.25-1.59)$ & 0.33 & & \\
\hline Nausea & Yes vs. no & $0.46(0.13-1.59)$ & 0.22 & & \\
\hline Sneeze & Yes vs. no & $3.28(0.45-23.72)$ & 0.24 & & \\
\hline Nasal congestion & Yes vs. no & $1.07(0.11-10.47)$ & 0.95 & & \\
\hline Nasal discharge & Yes vs. no & $1.97(0.46-8.46)$ & 0.36 & & \\
\hline \multicolumn{6}{|l|}{ CT findings } \\
\hline Ground glass opacity & Yes vs. no & $0.72(0.37-1.40)$ & 0.33 & & \\
\hline
\end{tabular}


medRxiv preprint doi: https://doi.org/10.1101/2020.04.28.20083246; this version posted May 3, 2020. The copyright holder for this preprint (which was not certified by peer review) is the author/funder, who has granted medRxiv a license to display the preprint in perpetuity. It is made available under a CC-BY-NC-ND 4.0 International license.

\begin{tabular}{|c|c|c|c|c|c|c|}
\hline \multicolumn{2}{|l|}{ Reticular pattern } & Yes vs. no & $1.07(0.55-2.08)$ & 0.85 & & \\
\hline \multicolumn{2}{|c|}{ Interstitial thickening } & Yes vs. no & $1.29(0.73-2.27)$ & 0.38 & & \\
\hline \multicolumn{2}{|c|}{ Crazy paving appearance } & Yes vs. no & $1.06(0.43-2.62)$ & 0.90 & & \\
\hline \multicolumn{2}{|l|}{ Consolidation } & Yes vs. no & $2.17(1.19-3.96)$ & 0.011 & & \\
\hline \multicolumn{2}{|l|}{ Bronchiectasis } & Yes vs. no & $2.49(1.05-5.91)$ & 0.039 & & \\
\hline \multicolumn{2}{|c|}{ Bilateral involvement } & Yes vs. no & $1.62(0.71-3.69)$ & 0.25 & & \\
\hline \multicolumn{2}{|c|}{ Multicentric pattern } & Yes vs. no & $1.20(0.64-2.25)$ & 0.58 & & \\
\hline \multicolumn{7}{|c|}{ Laboratory findings } \\
\hline \multicolumn{7}{|c|}{ Hematologic indices } \\
\hline Leukocyte & $\times 10^{\wedge} 9 / \mathrm{mL}$ & $>9.5$ vs. $\leq 9.5$ & $10.44(4.75-22.95)$ & $5.23 * 10^{-9}$ & & \\
\hline Neutrophil & $\times 10^{\wedge} 9 / \mathrm{mL}$ & $>6.3$ vs. $\leq 6.3$ & $9.56(4.87-18.77)$ & $5.42 * 10^{-11}$ & $32.77(7.60-141.26)$ & $3.00 * 10^{-6}$ \\
\hline \multirow[t]{2}{*}{ Lymphocyte } & $\times 10^{\wedge} 9 / \mathrm{mL}$ & $>1.1$ vs. $\leq 1.1$ & $0.34(0.17-0.66)$ & 0.001 & & \\
\hline & & $>0.5$ vs. $\leq 0.5$ & $0.47(0.25-0.92)$ & 0.03 & & \\
\hline Monocyte & $\times 10^{\wedge} 9 / \mathrm{mL}$ & $>0.6$ vs. $\leq 0.6$ & $2.95(1.62-5.37)$ & $4.14 * 10^{-4}$ & & \\
\hline Eosinophil & $\times 10^{\wedge} 9 / \mathrm{mL}$ & $>0.02$ vs. $\leq 0.02$ & $0.19(0.10-0.36)$ & $0.00 \mathrm{E} 0$ & & \\
\hline Basophil & $\times 10^{\wedge} 9 / \mathrm{mL}$ & $>0.06$ vs. $\leq 0.06$ & $1.66(0.48-5.72)$ & 0.42 & & \\
\hline Platelet & $\times 10^{\wedge} 9 / \mathrm{mL}$ & $>125$ vs. $\leq 125$ & $0.35(0.19-0.62)$ & $3.94 * 10^{-4}$ & & \\
\hline \multicolumn{7}{|l|}{ Hepatic function } \\
\hline ALT & $\mathrm{U} / \mathrm{L}$ & $>40$ vs. $\leq 40$ & $1.47(0.78-2.79)$ & 0.23 & & \\
\hline AST & $\mathrm{U} / \mathrm{L}$ & $>40$ vs. $\leq 40$ & $2.62(1.43-4.80)$ & 0.002 & & \\
\hline TBIL & $\mu \mathrm{mol} / \mathrm{L}$ & $>17.1$ vs. $\leq 17.1$ & $4.27(2.17-8.40)$ & $2.55 * 10^{-5}$ & & \\
\hline DBIL & $\mu \mathrm{mol} / \mathrm{L}$ & $>7$ vs. $\leq 7$ & $6.50(3.25-13.01)$ & $1.20 * 10^{-7}$ & $14.48(2.79-75.22)$ & 0.001 \\
\hline \multicolumn{7}{|l|}{ Renal function } \\
\hline Urea & $\mathrm{mM}$ & $>7.1$ vs. $\leq 7.1$ & $5.24(2.82-9.72)$ & $1.55^{*} 10^{-7}$ & & \\
\hline Creatinine & $\mu \mathrm{M}$ & $>115$ vs. $\leq 115$ & $6.43(2.75-15.03)$ & $1.72 * 10^{-5}$ & $23.22(2.40-224.35)$ & 0.007 \\
\hline \multicolumn{7}{|c|}{ Coagulation function } \\
\hline Prothrombin time & $\mathrm{s}$ & $>14$ vs. $\leq 14$ & $3.66(1.92-6.98)$ & $8.17 * 10^{-5}$ & & \\
\hline APTT & $\mathrm{s}$ & $>37$ vs. $\leq 37$ & $1.19(0.65-2.18)$ & 0.56 & & \\
\hline \multirow[t]{2}{*}{ D-dimer } & $\mu \mathrm{g} / \mathrm{mL}$ & $>0.55$ vs. $\leq 0.55$ & $3.40(1.67-6.94)$ & 0.001 & & \\
\hline & & $>2$ vs. $\leq 2$ & $3.47(1.86-6.47)$ & $8.80 * 10^{-5}$ & & \\
\hline \multicolumn{7}{|l|}{ Myocardial injury } \\
\hline \multirow[t]{2}{*}{ CK-MB } & $\mathrm{U} / \mathrm{L}$ & $>0.6$ vs. $\leq 0.6$ & $3.35(1.33-8.43)$ & 0.010 & & \\
\hline & & $>6$ vs. $\leq 6$ & $2.86(1.42-5.79)$ & 0.003 & & \\
\hline \multirow[t]{2}{*}{ Troponin } & $\mathrm{ng} / \mathrm{ml}$ & $>0.1$ vs. $\leq 0.1$ & $1.30(0.68-2.48)$ & 0.42 & & \\
\hline & & $>5$ vs. $\leq 5$ & $3.56(1.64-7.71)$ & 0.001 & $5.57(1.15-27.10)$ & 0.033 \\
\hline \multicolumn{7}{|c|}{ Infection-related indices } \\
\hline \multirow[t]{2}{*}{ CRP } & $\mathrm{mg} / \mathrm{L}$ & $>10$ vs. $\leq 10$ & $5.60(2.11-14.88)$ & 0.001 & & \\
\hline & & $>100$ vs. $\leq 100$ & $5.92(2.70-13.01)$ & $9.00 * 10^{-6}$ & & \\
\hline \multirow[t]{2}{*}{ hsCRP } & $\mathrm{mg} / \mathrm{L}$ & $>5$ vs. $\leq 5$ & $3.38(1.42-8.06)$ & 0.006 & & \\
\hline & & $>100$ vs. $\leq 100$ & $5.48(2.25-13.38)$ & $1.87 * 10^{-4}$ & & \\
\hline \multirow[t]{2}{*}{ Procalcitonin } & $\mathrm{ng} / \mathrm{mL}$ & $>0.1$ vs. $\leq 0.1$ & $3.07(1.60-5.91)$ & 0.001 & & \\
\hline & & $>0.5$ vs. $\leq 0.5$ & $5.56(2.54-12.18)$ & $1.82 * 10^{-5}$ & & \\
\hline
\end{tabular}

$406 p$ values were calculated by univariable or multivariable logistic regression. Abbreviations: NA=not applicable.

$407 \mathrm{COPD}=$ chronic obstructive pulmonary disease. ALT=alanine aminotransferase; AST=aspartate aminotransferase; 408 TBIL=total bilirubin; DBIL=direct bilirubin; APTT=activated partial thromboplastin time; $\mathrm{CK}-\mathrm{MB}=\mathrm{creatine}$ kinase-MB; $409 \mathrm{CRP}=\mathrm{C}$-reactive protein; hsCRP=high sensitivity $\mathrm{C}$-reactive protein; LHM= Lymphohematopoietic cancer. 
medRxiv preprint doi: https://doi.org/10.1101/2020.04.28.20083246; this version posted May 3, 2020. The copyright holder for this preprint (which was not certified by peer review) is the author/funder, who has granted medRxiv a license to display the preprint in perpetuity.

It is made available under a CC-BY-NC-ND 4.0 International license .

\section{Figure 1}

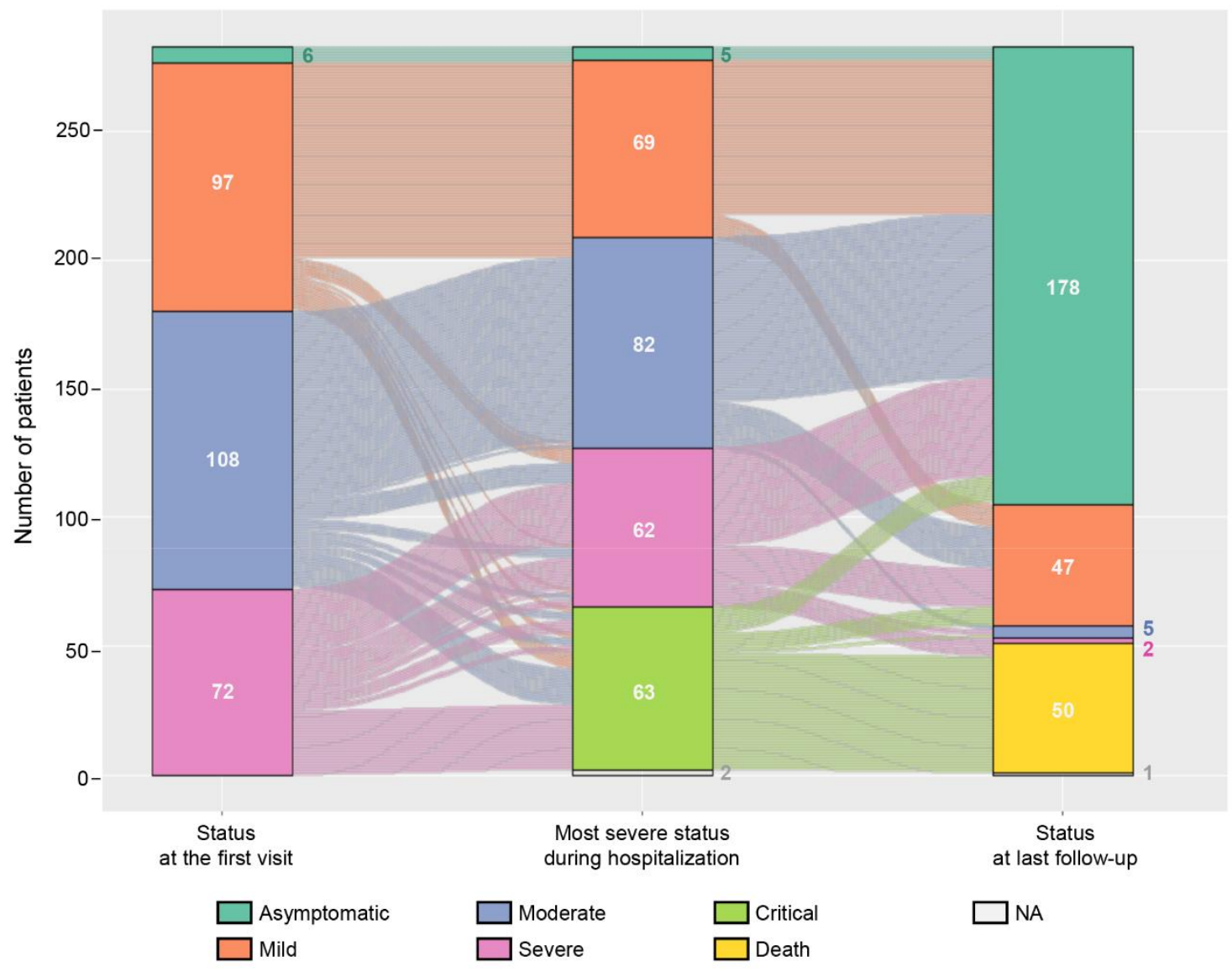

412 Figure 1. Clinical course of the patients in the study. Clinical evaluations of the patients were 413 shown from their onset illness (left), most severe severity level (middle), to last follow-up visit (right).

414 The patients with different severity levels were demonstrated in different colors. 


\section{Figure 2}

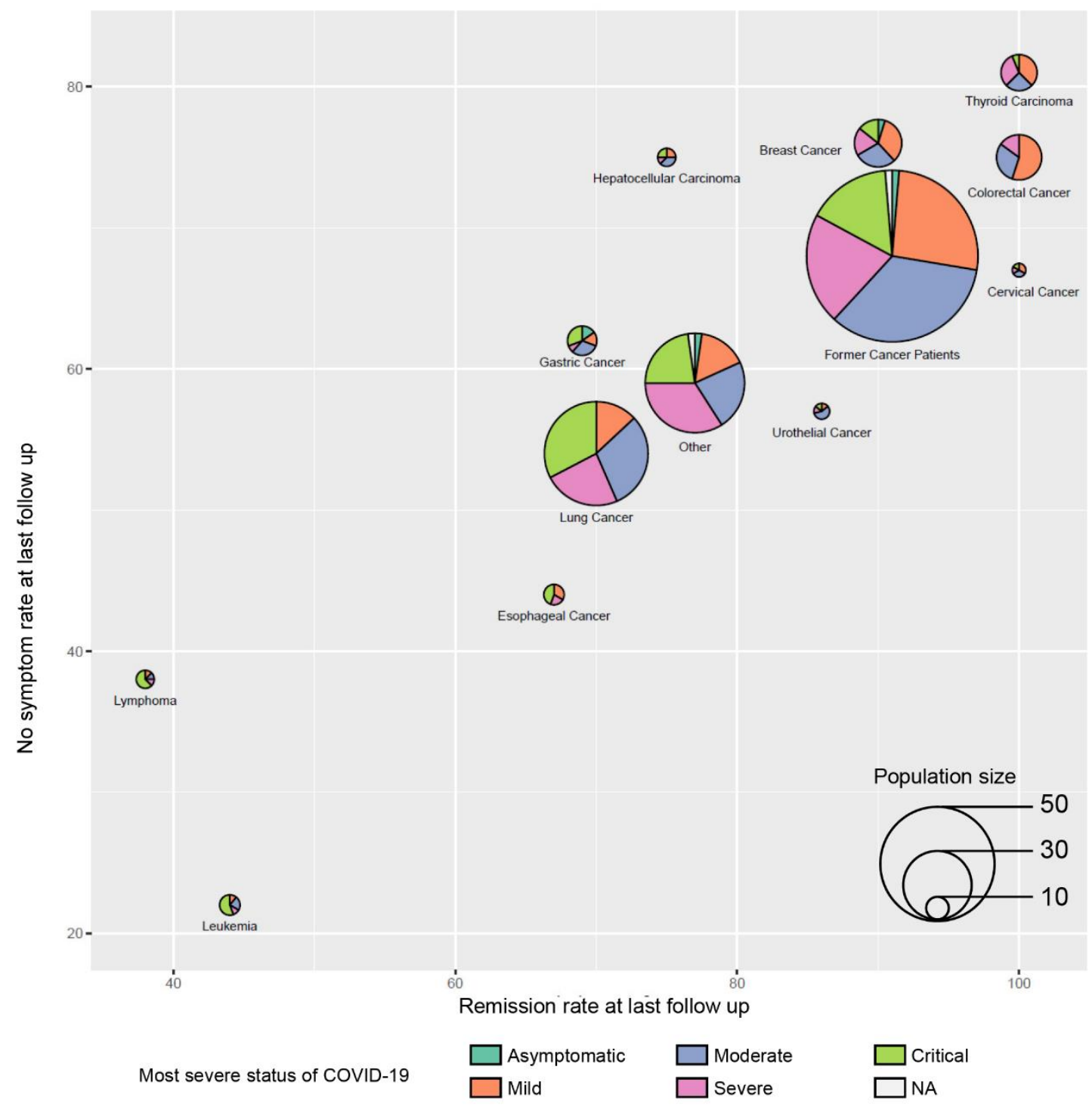

417 Figure 2. Illustration of the multidimensional outcomes of former cancer patients and the 418 current cancer patients with different tumor types with COVID-19. Each pie represents one group

419 of current cancer patient with a specific type of cancer, the former cancer patients were illustrated as 420 a separate group. The y coordinate of each pie center represents the rate of patients with no symptoms 421 at the last follow-up visit; the $\mathrm{x}$ coordinate represents the rate of remission at last follow-up visit; the 422 composition within each pie represents the distribution of most severe symptom levels in each tumor 423 type; the size of the pie represents the population size as demonstrated in the inset. Tumors with the 424 population size less than 10 are not shown in the figure and were considered as "other". 


\section{Figure 3}

A

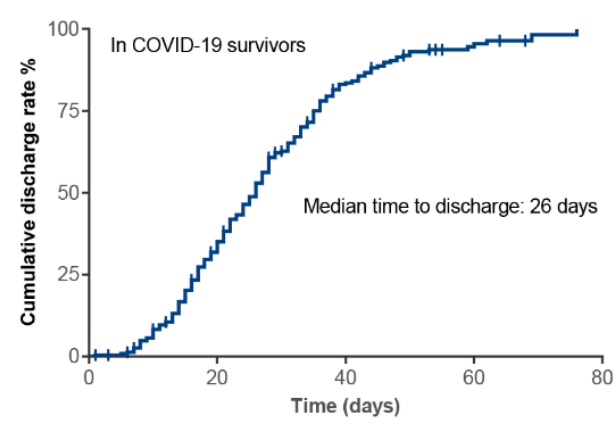

No. at risk $233 \quad 151$

C

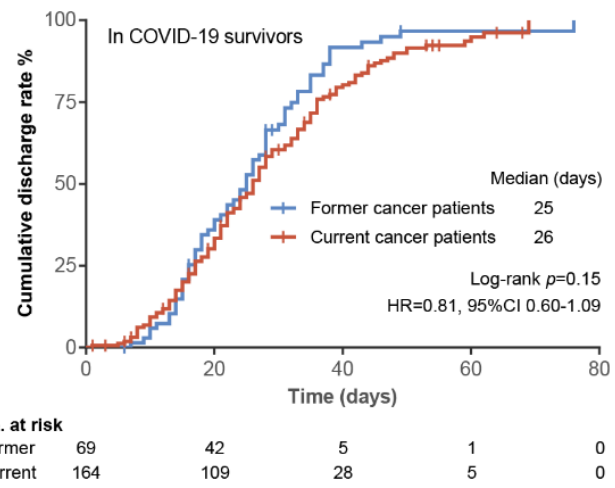

B

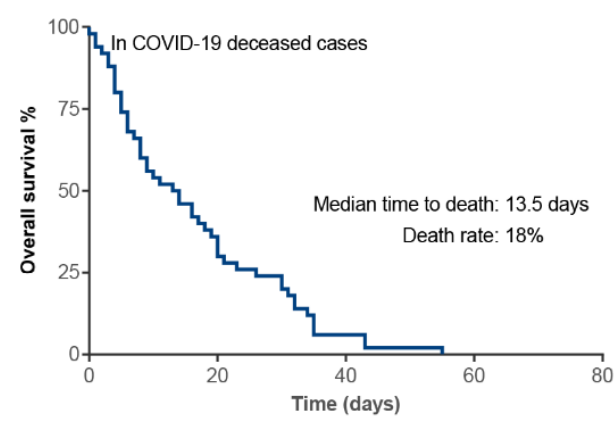

No. at risk $50 \quad 18$

D

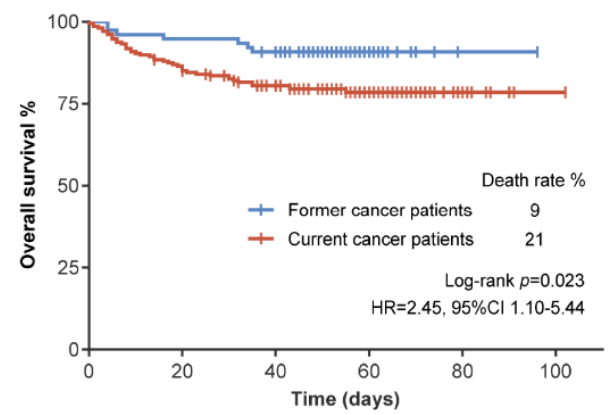

No. at risk

$\begin{array}{lcccccc}\text { No. at risk } & & & & & & \\ \text { Former } & 76 & 72 & 68 & 23 & 1 & 0 \\ \text { Current } & 207 & 178 & 152 & 60 & 8 & 1\end{array}$

425

426 Figure 3. Kaplan-Meier curves of the outcomes of the patients. (A) Kaplan-Meier curves of the

427 hospitalization stay of the overall survivors. (B) Kaplan-Meier curve of the time to death in COVID-

42819 deceased cases. (C) Kaplan-Meier curves comparing the hospitalization stay of survivors between

429 the former and current cancer patients. (D) Comparison of the overall survival between the former 430 and the current cancer patients. 